University of Rhode Island

DigitalCommons@URI

Open Access Master's Theses

1989

\title{
Transformational and Transactional Church Leadership Perspectives of Pastors and Parishioners
}

James L. Bray

University of Rhode Island

Follow this and additional works at: https://digitalcommons.uri.edu/theses

\section{Recommended Citation}

Bray, James L., "Transformational and Transactional Church Leadership Perspectives of Pastors and Parishioners" (1989). Open Access Master's Theses. Paper 1632.

https://digitalcommons.uri.edu/theses/1632

This Thesis is brought to you for free and open access by DigitalCommons@URI. It has been accepted for inclusion in Open Access Master's Theses by an authorized administrator of DigitalCommons@URI. For more information, please contact digitalcommons-group@uri.edu. 
TRANSFORMATIONAL AND TRANSACTIONAL

CHURCH LEADERSHIP PERSPECTIVES

OF PASTORS AND PARISHIONERS

BY

JAMES L. BRAY

A THESIS SUBMITTED IN PARTIAL FULFILLMENT OF THE REQUIREMENTS FOR THE DEGREE OF

MASTER OF ARTS

IN

PSYCHOLOGY 


\section{ABSTRACT}

The conceptual model of Transformational/Transactional leadership nas been drawn primariiy from case studies of business leaders and political figures. No empirical studies of these concepts appear to exist. There are no studies that operationalize these concepts in a religious setting. This research, therefore, operationalizes and extends these leadership perspectives into a religious setting.

A review of the social science literature as well as the Biblical literature suggested the particular importance of the Transformational leader providing a Model, being involved in a wide Breadth of interests, and Persevering. The Transactional leader, on the other hand, is less concerned about providing an example, is interested only in a few specific areas, and is likely to conform. The question is raised whether pastors and parishioners have diverging views regarding these leadership concepts. If so, a second question is raised as to whether this difference has an impact on pastoral tenure. Three basic assumptions of this research are that there is a difference between pastors and parishioners along Transformational/Transactional 1ines, that this difference leads to friction between congregants and pastors, and that this friction causes pastors to have brief tenures. It is assumed that tenures of more than six years would be healthier than the brief tenures that are the norm. My hypothesis was that pastors would list proportionately more Transformational statements than parishioners on the questionnaire. This hypothesis was tested through an open-ended questionnaire developed by the author and administered to pastors and parishioners; subjects were drawn from Conservative Baptist churches in New England. As hypothesized, pastors are more Transformational than 
parishioners; responses to the questionnaire demonstrate a significant difference between these pastors and parishioners on the major Transformational/Transactional distinction, as well as, on the subconcepts of Persevering and of Breadth of Invoivement. Directions for future research are out lined. 
ACKNOWLEDGEMENTS

First, I thank my wife and co-coder, Lynn, for her encouragement and assistance.

Second, I thank my committee for their time, attention, and support. Special thanks to Dr. Albert Lott who guided me through the early research and patientiy saw me through the project. Or. Sandra ketrow is to be thanked for sharing her background in leadership research and for her challenge for completeness. I thank or. John Stevenson for holding out basic questions and for insisting on quality.

Third, I thank several professors in and out of the department who gave me some time here and there; I thank two professors who especialiy would have 1 iked to have been on the committee, but were good enough to say "no" when they realized their limited time or expertise would hinder the project; and I thank my fellow students for their interest and help.

Fourth, I thank the pastors and parishoners who sincerely and thoroughly responded to the questionnaire.

Fifth, I thank God for the opportunity to further the ministry He has given me and potentially to further the ministries of several pastors and congregations. 
Table of contents

Pages

Abstract

Acknow ledgements

iv

Table of contents

$\checkmark$

List of Tables and Appendices

$v i$

Introduction

1

Contemporary Views of Leadership . 1

Transformational and Transactional Leadership 3

Leadership in the Church 5

$\begin{array}{ll}\text { Procedure } & 9\end{array}$

Developing the Questionnaire 9

Developing the Pilot Study Coding Manual 12

$\begin{array}{ll}\text { Pilot Study } & 14\end{array}$

$\begin{array}{ll}\text { Main Study } & 16\end{array}$

$\begin{array}{ll}\text { Discussion } & 25\end{array}$

$\begin{array}{ll}\text { Appendices } & 38\end{array}$

Bibliography 
Tables

Pages

Table 1--Items of Contrast Between Transformational

and Transactiona 1 Leaders

Table 2--Responses of Pastors and Parishioners

to Leadership Questionnaire

Table 3--Mean Numbers of Responses of Pastor

and Parishioner Groups

Appendices

Appendix 1--Summary of Verse By Verse Analysis

of the Pastoral Epistles

Appendix 2--Questionnaire

Appendix 3--Verification of Question Grouping

Appendix 4--Pilot Study Coding Manual

48

Appendix 5--Informed Consent Form

49

Appendix 6--Main Study Coding Manual 50

Appendix 7--Love's Centrality 
This study was an attempt to discover whether pastors and parishioners or congregants differ in their expectations of church leadership along transformational and transactional 1 ines. Transactional leaders concern themselves with what is necessary to maintain the status quo; transformational leaders concern themselves with those things necessary for the organization, product, or people to reach potential. The study surveyed parishioners and ministers within my denomination, Conservative Baptists of America, in New England. It was assumed that differing perspectives of the leader's roles would be found and that if found, this line of inquiry might eventually help account for the gap between a theoretically ideal pastoral term (ten years) and the more frequently observed term of less than three years.

Personally, as a minister I am interested in facilitating cooperation between pastors and congregations. As a student of psychology I am interested in testing the transformationa1/transactional leadership distinctions on a specific population. Leadership is important; dynamic and effective leadership separates successful from unsuccessful organizations according to Hersey and Blanchard (1972; p. 67).

Contemporary Views of Leadership

What are some of the major, current approaches to studying leadership? Gordon (1987) lists five: the trait perspective, the behavioral view, the situational models, the attributional mode1, and 
the operant conditioning model. Hollander's (1985) review listed the "hereditary and instinct" approach, as we11; he said: "The idea that 'leaders are born, not made' still has wide appeal, even though it has been largely discredited" $(p .490)$. The trait perspective (we should evaluate leaders by personality and social traits and physical characteristics) and one of the situational models, the Fiedler Contingency Theory (effective leadership style is dependent upon the situation), have received the most interest. Concerning the trait theory, Gordon (1983) refers to Stodgi11's work (1974) and to Ghiselli's work (1971) in concluding that the traits associated with leadership in one situation do not predict leadership in other situations; she says "no clear pattern of which traits make an effective leader has emerged" (p. 394). Andriessen and Drenth (1984) agree with Gordon, when they say that interest in the trait approach to leadership has waned since the 1950's, because few traits could be found that distinguish between "good and bad leaders, or between leaders and followers" (p. 487). Gordon (1987), as opposed to the majority of theorists reviewed here, sees the charismatic personality as important to Transformational leadership and, therefore, sees the study of Transformational leadership as a return to trait theory ( $p$. 395). Other theorists seem not to stress the individual traits, which were studied in the past, but the interactive roles or the interactional dimensions; I tend to follow this majority position. In discussing Fiedler's Contingency Theory, Gordon refers to criticisms by Barrow (1977), by Singh (1983), and by Hosking and Schriesheim (1978); a major concern is that the theory fails to predict effective leadership. The behavioral view concentrates on a given leader's 
actions; often, this approach evaluates whether a leader is basically authoritarian, democratic or laissez-fare in dealing with subordinates. The attributional view is that leadership exists only as an individual's perception, not as an objective factor of a situation. The operant conditioning model studies the repeated interaction of leader and subordinates as they reinforce, punish, or extinguish the behavior of one another.

No one leadership theory has emerged as dominant; Hollander (1985) quates sims (1977) as saying: "Leadership is perhaps the most researched and least understood area of organizational behavior" ( $p$. 488). Andriessen and Drenth (1984) state that it is unclear what the relevant dependent variables are in leadership research; they fault the lines of research for staying with correlational studies, which fail to get at causal relations and for using simplistic theoretical models in light of the complexity of the leader-follower interaction (pp. 482483).

Transformational And Transactional Leadership

In this section the Transformational and Transactional leadership styles are detailed and Biblical counterparts to these leader behaviors are identified. The author has observed that theoretical statements on leadership found in psychological material seem to fit with Biblical orientations to leadership.

Burns (1978), in a historical survey contends that political leaders who have made a significant impact have been Transformational. Transformational leaders do more than maintain the status quo--they 
help their followers reach their potential (Bass, 1985). Harris (1985) sees the Transformational manager as the one able to lead into the future. A Transactional leader, on the other hand, directs his or her attention to maintaining the status quo; avoids risks; holds to current margins and levels of activity; goes by the old maxim: "if it ain't broke, don't fix it." A Transactional leader seeks to keep his or her followers and organization happy by meeting expressed needs; he or she interacts with them economically (exchanging money for effort), politically (exchanging jobs for votes), or psychologically (exchanging nurturance for respect). While not neglecting expressed needs, the Transformational leader seeks to identify higher (self-actualizing) needs and to mobilize his or her followers and organization to meet those needs. A Transformational leader is interested in improving product, morale, methods, and margins; he or she is inquisitive-asking: "what if?", innovative--desiring to be on the cutting edge, and willing to take risks. He or she seeks to motivate, engage, and stimulate a follower to give of himself or herself to meet the new goals. Innovation and change are often needed for the followers and organization to reach their potential. Bass (1985, p. 20) paraphrases William F. Buckley as saying that the Transformational leader is one who "'crystallizes' what it is that people desire, 'illuminates' the rightness of that desire, and coordinates its achievement." Tichy and Ulrich (1984) summarize the expectations of Transformational leadership:

"What is required of this kind of leader is an ability to help the organization to develop a vision of what it can be, to mobilize the organization to accept and work toward achieving the new vision, and to institutionalize the changes that must last over time." 
Gordon (1987) says that Transformational leaders change

organizations in four ways:

"They identify the triggers for a major change. They create a vision of the change. They become personally committed to the change and obtain subordinates' commitment as well. Finally, they institute change by managing the organization's structure, management processes, culture, and human resources" (p. 702).

Levy and Merry (1986) list these characteristics of Transforming leaders from Deal and Kennedy's (1982) work:

"They are highly visible, credible, and consistent in support of the values they espouse.

They are masters of communication.

They use symbolic actions such as rites, rituals, and ceremonies to reinforce their values.

They motivate employees by providing positive reinforcement.

They provide a lasting human climate within the system.

They know how to succeed and to make change attainable and part of human capacity.

They provide positive role models for workers to follow.

They set high standards of performance.

They encourage creativity, innovation, and trial and error" (p. 53).

Some of the distinctions that Harris (1985, p. 21) makes between what he calls the "traditional manager" and the "transformational manager" will help to clarify some of the differences between the Transactional and the Transformational leader: slow to act versus forcefully acts, past-oriented versus future-oriented, short-term oriented versus long-term oriented, plays it safe versus on the cutting edge, conformity versus initiative, pragmatic versus conceptualizer, and concern for average performance versus sets high personal and professional standards for self and others.

Leadership In The Church

What are the Biblical concepts of church leadership? The nature 
and functions of the church suggest that leadership within the church would ideally be Transformational. The Apostle Paul commands the church at Rome to be "transformed" (Romans 12:2); the Greek word, "metamorphoo", used here gives us the English word "metamorphosis". Paul is writing to those who are already part of a local church; the context is conformity to a way of planning or thinking--"Do not conform any longer to the pattern of this world, but be transformed..." The Bible itself seems to stress among other Transformational aspects of pastoral leadership these three: modeling--"(s)et an example for the believers in speech, in life, in love, in faith, and in purity" (II Iimothy 4:12), perse verence--"Until I come, devote yourself...Do not neglect... Be diligent in these matters; give yourself wholly to them...Persevere..." (II Iimothy 4:13-16), and involvement in a breadth of ministry (versus a limited, chaplain-like involvement)--"(D)irect the affairs of the church..." (I Iimothy 5:17) and "Preach the Word...correct, rebuke, encourage...do the work of an evangelist, discharge al1 the duties of your ministry..." (II Iimothy 4:2-5). These distinctions were found by the author in a study of the Pastoral Epistles; these letters are commonly regarded within the above denomination as outlining the expectations (requirements) of church leaders.

In a verse by verse analysis of the above epistles several additional categories were found: title or position, personal relationships, needs to be met, things to avoid, and general qualifications (no justification was found to consider any of these additional categories as Transformational or Transactional concerns and, therefore, they are not considered in this proposal--see Appendix 
1).

Bandura's (1986) analysis of motivation and learning lends credence to the Biblical priority of modeling; as well, Deal and Kennedy (1982) according to Levy and Merry (1986) referred to "positive role models" in the list mentioned earlier. Transformational change is rewarded only after an extended time, whereas Transactional change may be rewarded relatively quickly. Because followers do not see the rewards of Transformational change as quickly as they do a Transactional change, the need for greater perseverence in a Transformational leader can be seen intuitively. Harris (1985; p. 21) seems to support this intuition when he notes the long-term orientation of the Transformational leader (mentioned earlier). Harris alsa notes that as a "conceptualizer" a Transformational leader "links together pieces and parts into a whole"; such a leader must attend to the whole, to the breadth of ministry concerns.

Do parishioners and pastors have different views regarding these concepts? This is the question this study sought to answer. If they have different views, could this difference have a significant impact on pastoral tenure (i.e., does tension result and cause a pastor to be fired or to resign under pressure?) and other aspects of pastorparishioner relationship? Christian leaders have been voicing concern about this issue since I entered ministry. George (1987) says despite the tendency for short pastorates, "... a pastor's most effective period of ministry comes after the sixth year, according to many church observers." On April 28, 1988 I spoke with Dwane Shockly, a leader in my denomination (the Conservative Baptists of America); he says the 
average pastorate in our sister denominations in the U.S. is approximately three years and in our denomination it is only sightly longer. That same day I talked to Vince Rutherford of the charles $E$. Fuller Institute of Church Growth and Evangelism. He says Baptist pastors stay an average of two years in a church and this despite the Institute's conviction that a pastor becomes most effective in six to ten years.

Three basic assumptions of this research are that there is a difference between pastors and parishioners in their perceptions of Transformational and Transactional leadership positions, that this difference leads to friction between congregants and pastors, and that this friction causes pastors to have brief tenures. It is assumed that tenures of more than six years would be more productive than the brief tenures that are the norm. For the purpose of this study I will test only the first assumption. My hypothesis is that pastors will list proportionately more Transformational statements than parishioners on the questionnaire.

The conceptual model of Transformational/Transactional leadership has been drawn from case studies of business leaders and political figures. To my knowledge there are no empirical studies of these concepts; and I am quite certain that there are not any studies that operationalize these concepts in a religious setting. This research will therefore undertake the development of empirical definitions and extend these leadership perspectives into a religious setting. 
Developing The Questionnaire

An open-ended questionnaire (see Appendix 2) was developed and tested in a pilot study. An open-ended format was used in an attempt to obtain a rich and varied set of responses in this initial work. The responses to this questionnaire were later subjected to a content analysis to assess the following aspects of Transformational and Transactional leadership:

Several questions look at the basic TRANSFORMATIONAL/TRANSACTIONAL distinction--

7--How does a minister keep a church running smoothly (1ist)? 8--How does a minister help a church reach its potential (1ist)? 9--A church must look to the future. How can a minister lead his church to the future (list)?

12--I think a minister should provide leadership in the following areas (1ist)

13-- I think a minister should not provide leadership in the following areas (1ist) and

14--If a minister is an effective leader, how would his church differ from other churches (1ist)?

The MODELING aspect is addressed in two questions--

17--If a minister were to inspire someone to follow him, what would that minister be like or how would he behave (list)? and 18--You may have heard the old adage: "Some things are better caught than taught." What habits, convictions, traits, or the 
like would you expect a member to "catch" from a minister (1 ist)?

Four questions relate to PERSEVERENCE--

5--How many years should a minister plan to stay in any given church? _ years

6--In what year of ministry in any given church does a minister reach his peak of effectiveness? _ year

19--If a congregation does not favor a certain idea that is important to a minister, how should he react? and

20--If a congregation favors a certain idea, but the minister does not favor it, how should he react?

Four questions are concerned with BREADTH OF INVOLVEMENT--

10--In your experience, in what areas of church life does a congregation expect a minister to take leadership ( 1 ist)?

11--In your experience, in what areas of church life does a minister expect to take leadership ( 1 ist)?

15--What functions or activities might a minister delegate to lay people (1ist)? and

16--What functions or activities might a minister reserve for himse1f ( 1 ist)?

The remaining questions include potential variables for future research: questions $1,2,3$, and 4 seek to discover age, sex, years of membership for congregants or years of tenure for pastors, and years as Christian; question 21 reads: "Suppose a minister wants a church to adopt some change. Should he seek that change through his pulpit ministry, church boards, personal relationships, business meetings, or 
some other means? Please explain your answer."

To verify that the questions addressed the issues I assumed they did, the aid of three fellow Psychology graduate students was enlisted to individually group (cluster) the questions. Each of the students was given a letter found in Appendix 3. The letter explained I needed to verify that research questions got at the issues for which they were intended. It also included definitions for Transformational and Transactional leadership, modeling, perseverence, and breadth of involvement. The letter explained that they were being asked to sort twenty-one (21) cards, each with a question on it, into one of five groups. The Pilot Study Coding Manual (see Appendix 4) was referred to in order to respond to their questions. Five slips of paper were placed on a table and each student was asked to group the questions (which were on otherwise blank cards) into five groups: Transformationa1/Transactional Basic Distinctives; Modeling; Persevering; Breadth of Involvement; or Follow up Research. The entire process took approximately ten (10) minutes per student.

The three agreed with each other and my own perspective of the questions with the following exceptions: one student saw Questions 12 and 13 as 'Modeling', while the others saw them as 'Breadth of Involvement'; one student saw Question 21 as related to Modeling, a second as the basic Transformational/Transactional concern, and the third as Breadth of Involvement. Since the questionnaire in general seemed to tap those areas for which it was constructed, it was decided to wait until a pilot study was run to finally decide if \#12 and \#13 should be included in the main study. Since \#21 was pointed at future study, the difference in opinion was of no consequence. I took this 
grouping process to be adequate justification for grouping the questions as presented in my proposal. Thus, the instrument was considered to have face and content validity.

Developing The Pilot Study Coding Manual

Because the responses to the open-ended questions would have to be coded as to whether they were Transformationa1, or Transactional, or neither, a coding manual was developed. It was written in a letter format to volunteers who would code the questionnaires. It explained that the volunteers would need to understand the distinction between Transformational and Transactional perspectives in order to categorize and label questionnaire responses. These two concepts were briefly defined in general. Following this, more specific distinctions were drawn by listing in parallel columns (under the headings of Transformational and Transactiona1) twenty-four items of contrast between these two leadership concepts (see Table 1). These items of contrast were taken from literature reviewed herein; Harris's (1985) chapter, "Transforming Work, Organizations, and Management", gave me the idea of columns of contrasts and was the source of several specific contrasts. 


\section{LEADERS}

TRANSFORMATIONAL

future oriented

willing to take risks

interested in improving

innovative

inquisitive

forcefully acts

long-term oriented

on the cutting edge

intitiative

conceptual

concerned with high standards

comfortable with change

willing to make waves

broad interests

willing to invest

growth conscious

willing to take a stand

transforming

comfortable with shifts in power

visionary

ahead of the pack

freeing--the sky is the limit comfortable even without limits interested in moral implications asking: what if?

concerned beyond expressed needs comfortable with pressure comfortable with shifts in expectations

makes fundamental changes
TRANSACT IONAL

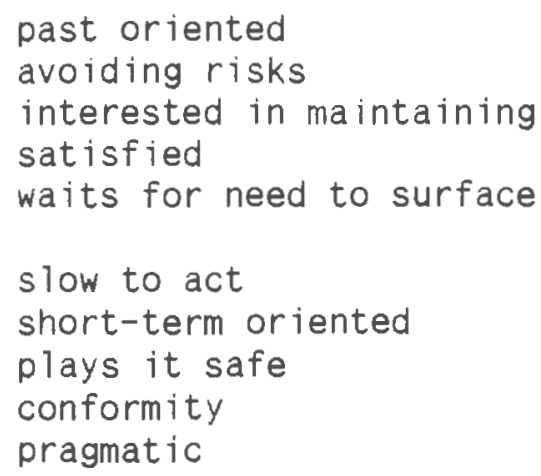




\section{Pilot study}

\section{Subjects}

Subjects included five ministers and and six parishioners. Four of the ministers were part of a conservative Baptist minister's committee on which I serve; the fifth was my co-pastor. The parishioners were part of a mid-week service in my Conservative Baptist church in Rhode Is land. These volunteers signed an informed consent form (see Appendix 5).

\section{Procedure}

Subjects were told that the purpose of the questionnaire was to gather opinions about church life. Subjects were asked to answer all questions and to list their answers. Subjects filled the questionnaires out on their own time and returned them to me at their convenience.

\section{Coding}

For the Pilot study my wife and I were the two independent raters. She was quite familiar with the Transformational/Transactional distinctions and I briefed her on the Pilot study Coding Manual (see Appendix 4). For questions requiring a list, subjects were asked to carefully 1 ist and number their responses; thus, the unit of analysis was determined by each person filling out the questionnaire. Each response received a code, such that any given respondent for any given question might have one or more responses coded as Transformational, one or more responses as Transactional, or one or more responses as other. For each question responses were totaled across all pastors to be compared to the responses for all parishioners. 
Results

The pilot study was done to assist in the refinement of the questionnaire and coding process. In general, the pilot study confirmed the usefulness of the questionnaire. However, coders did find questions 15 and 16 on Breadth of Involvement difficult. Question \#15 had read: What functions or activities might a minister delegate to lay people (1ist)? and Question \#16 had read: What functions of activities might a minister reserve for himself? Transformational leaders tend to become involved broadly (Breadth of Involvement); these questions were interided to demonstrate whether pastors and parishioners differed regarding their expectation of how broadly a minister might be involved. For both questions the coders were not sure if respondents were willing to free ministers from some concerns or if they were trying to restrict ministers from the same concerns. An example of a response difficult to code is "finance"; the question arises whether the response means that a minister should not have to waste his time with a mundane matter like counting pennies and nickels or whether the response means that a minister should not take budget setting and fund raising matters into his hands. These questions were reworded after the Pilot study in an attempt to avoid confusion for the coders. For the Main Study Question \#15 read: In what functions or activities of the church should a minister be involved (1ist)? and Question \#16 read: In what functions or activities of the church should a minister not be involved (1ist)? For the Main Study the coding manual (see Appendix 6) was refined based upon the results of the pilot study: seven more items of contrast between Transformational and Transactional leadership were listed; a few of the items of contrast were reworded for clarity; a 
1ist of typical job description duties was added; and some specific coding instructions were given for some questions. Rater reliability for the fourteen open-ended questions was confirmed utilizing cohen's Kappa (Cohen; 1960): $K=0.95 ; z=8.6 ; p<0.05$.

\section{Main Study}

\section{Subjects}

Subjects were 33 ministers and 31 parishioners from Conservative Baptist churches. The ministers were gathered for a New England associational meeting; volunteers were requested through a public announcement at the meeting. The parishioners were from four churches-two in Rhode Island, and one each in Connecticut and Massachusetts; volunteers were sought from mid-week services. Participation was voluntary. The churches differed from one another in some ways: one was a sma11 rural church, which changes pastors frequently; another was a twelve year old inner-city church, which still has its founding pastor; a third church was in suburbia under a new pastor who is following a pastor with a thirty year tenure; the fourth is blue collar church with a history of pastorates of ten to twenty years tenure. All ministers were males; their average age was fifty (50). Parishioners averaged forty-nine (49) years of age. Parishioners included 12 males and 19 females; that breakdown reflected the attendance at the meetings in the experimenter's judgment. Al1 subjects signed an informed consent form (see Appendix 5).

\section{Procedure}

Subjects were told that the purpose of the questionnaire was to gather opinions about church life. subjects were asked to answer all 
questions and to list their answers. The ministers were individually approached at break-times at the two-day meeting; the experimenter remained nearby to answer any questions. The parishioners were encouraged to stay after the service, if they were willing to complete the questionnaire; the experimenter remained nearby to answer any questions. Subjects were told that it would take approximately 30 minutes to complete the questionnaire.

\section{Coding}

Two independent raters coded the results; they used the main study coding manual; this was an updated version of the pilot study coding manual--see Appendix $F$. The author and his wife were the coders. Both were very familiar with the leadership dimensions and the Main Study Coding Manual. The concerns of a Transformational leader and a Transactional leader often overlap; therefore in reviewing the manual I stressed that when the response fit both types of leaders, it should be coded as Transactional and only when the response was uniquely Transformational, could it be so coded. Regarding a Transactional leader I stressed that he is tied to job descriptions (fortunately, both coders are wel1 aware of a pastor's job description). In the third category, 'other', we placed those responses that were unclear, not to the point or not specifically Transformational or Transactional. Coders practiced by mock-coding and discussed the specific dimensions that led to specific conclusions. The coding process was done over several days; each day the coders reviewed the manual before begining to code. Rater reliability was checked and confirmed utilizing Cohen's Kappa (Cohen, 1960) after coding Questions 7-13: $K=0.98 ; \quad Z=980 ; p<0.05$. Rater reliability was checked and confirmed, again, at the completion of the 
coding process for all the open-ended questions: $K=0.98 ; \quad z=980$; $p<0.05$

For questions requiring a list, subjects were asked to carefully list and number their responses; thus, the unit of analysis was determined by each person filling out the questionnaire. Each response received a code, such that any given respondent for any given question might have one or more responses coded as Transformational, one or more responses as Transactiona1, and one or more responses as Other. For each question, responses were totaled across all pastors to be compared to responses for all parishioners. The study was designed for thirty pastors and thirty parishoners. Not knowing how many would return successfully completed questionnaires, extra copies were handed out. Prior to coding, questionnaires were reviewed for completeness; any questionnaires with unanswered open-ended questions were eliminated. A11 successfully completed questionnaires returned by pastors and parishioners were coded.

\section{Results}

chi-square analysis was used to compares responses of pastors and parishioners. The four Chi-Square cells included the pastors' Transformational and Transactional responses and the parishioners' Transformational and Transactional responses. A four-cell chi-square ( $d f=1$ ) is significant at the $p<0.05$ level at 3.841. Rather than the raw numbers, percentages were used; this was planned because I thought the pastors might tend to give more answers than parishioners; later, it proved useful, because more completed questionnaires were turned in from pastors than from parishioners. Thus, the four cells were: cell 
one--the percentage of pastors' Transformational responses compared to tota1 Transformational and Transactional responses; ce11 two--the similar percentage for the pastors' Transactional responses; cel1 three--the parishioners' Transformational percentage; and cell four-the parishioners Transactional percentage (see Tables 2 and 3). 
TABLE 2--RESPONSES OF PASTORS AND PARISHIONERS TO LEADERSHIP QUESTIONNAIRE

\begin{tabular}{|c|c|c|c|c|c|c|c|}
\hline \multirow[b]{2}{*}{ Question } & \multirow[b]{2}{*}{ Category } & \multirow{2}{*}{\multicolumn{2}{|c|}{ Pastors }} & \multirow{2}{*}{\multicolumn{2}{|c|}{ Parishioners }} & \multirow{2}{*}{$x^{2}$} & \multirow[b]{2}{*}{ Significance } \\
\hline & & & & & & & \\
\hline$\$ 7$ & Basic TF/TA* & 20 & 83 & 24 & 64 & 1.81 & NS \\
\hline$\# 8$ & Basic TF/TA* & 6 & 109 & 7 & 95 & 0.06 & NS \\
\hline$\# 9$ & Basic $T F / T A$ & 43 & 31 & 20 & 37 & 10.63 & $p<.05$ \\
\hline$\# 10$ & Breadth & 20 & 101 & 10 & 71 & 0.83 & NS \\
\hline$\# 11$ & Breadth & 19 & 90 & 11 & 54 & 0.00 & NS \\
\hline$\# 12$ & Basic TF/TA & 28 & 98 & 11 & 88 & 4.39 & $p<.05$ \\
\hline$\# 13$ & Basic TF/TA & 17 & 25 & 11 & 27 & 2.93 & NS \\
\hline$\# 14$ & Basic TF/TA & 19 & 47 & 8 & 59 & 8.87 & $p<.05$ \\
\hline$\# 15$ & Breadth & 8 & 99 & 10 & 65 & 1.80 & NS \\
\hline$\# 16$ & Breadth & 16 & 7 & 9 & 8 & 6.10 & $p<.05$ \\
\hline$\# 17$ & Mode 1 ing* & 26 & 57 & 32 & 54 & 0.80 & NS \\
\hline$\# 18$ & Mode 1 ing* & 33 & 56 & 19 & 53 & 2.80 & NS \\
\hline$\# 19$ & Perseverence & 32 & 4 & 9 & 6 & 22.13 & $p<.05$ \\
\hline
\end{tabular}

Four-ce11 Chi-square analysis:

[Pastor TF, Pastor TA, Parishioner TF, Parishioner TA]; significance at $p<0.05$ leve 1 is $3.841(d f=1)$

Note: TF--Number of Transformationa1 Responses (given in raw numbers) TA--Number of Transactional Responses (given in raw numbers) Basic TF/TA--Basic Transformational/Transactional category *--Responses dominated by love dimension; see Appendix 1 Breadth--Breadth of Involvement category Modeling--Modeling category Perseverence--Perseverence category 
TABLE 3--MEAN NUMBERS OF RESPONSES FOR PASTOR AND PARISHIONER GROUPS

PER PASTOR PER PARISHIONER
Number of Transformational Responses
10.3
6.7
Number of Transactiona1 Responses
24.0
21.1
Number of Other Responses
6.3
7.4
Number of Total Responses
40.6
35.2 
Six questions looked at the basic TRANSFORMATIONAL/TRANSACTIONAL distinction:

Question \#7--How does a minister keep a church running smoothly (1 ist)?

The results were not significant.

Question \#8--How does a minister help a church reach its potentidl ( 1 ist)?

The results were not significant.

Question \#9--A church must look to the future. How can a minister lead his church to the future (1ist)?

The results were significant at the 0.05 level with a chi square of $10.63(d f=1)$; the direction was as hypothesized (i.e., pastors were more Transformational than parishioners).

Question \#12--I think a minister should provide leadership in the following areas (1 ist)

The results were significant at the 0.05 level with a chi square of $4.39(d f=1)$; the direction was as hypothesized (i.e., pastors were more Transformational than parishioners).

Question \#13--I think a minister should not provide leadership in the following areas (1ist)

The results were not significant.

Question \#14--If a minister is an effective leader, how would his church differ from other churches (1ist)?

The results were significant at the 0.05 level with a chi square of $8.87(d f=1)$; the direction was as hypothesized (i.e., pastors were more Transformational than parishioners).

MODELING was addressed in two questions: 
Question \#17--If a minister were to inspire someone to follow him, what would that minister be like or how would he behave (1 ist)?

The results were not significant.

Question \#18--You may have heard the old adage: "Some things are better caught than taught." what habits, convictions, traits, or the like would you expect a member to "catch" from a minister (1 ist)?

The results were not significant.

PERSEVERENCE was measured in four questions:

Question \#5--How many years should a minister plan to stay in any given church? _years

Other than for this question and Question \#6, questionnaires were utilized only if all the questions were answered; incomplete questionnaires were not coded. Questions 5 and 6 were the only two nonopen ended questions. Twenty-six of 33 ministers and 27 of 31 parishioners answered this question. A number of subjects mentioned having difficulty with one or both questions. Several subjects suggested in their answers or orally that the number they were indicating was a minimum number by qualifying their answers as in "at least 5 years", etc. I had given oral instructions to try to put down a specific number of years. Since these qualifiers could not be quantified, they were ignored (for averaging purposes) and the whole numbers were averaged. Ministers' answers averaged 7.4 years and congregants averaged 14.6 years. A Median Test of significance was performed to see if the two distributions came from the same populations; there is a significant difference with $x^{2}=9.478$; 
$p<.05(d f=1)$.

Question \#6--In what year of ministry in any given church does a minister reach his peak of effectiveness? _year

Thirty of 33 ministers and 29 of 31 congregants answered this question. Ministers averaged 5.3 years and congregants averaged 5.65 years. A Median Test of significance was performed to see if the two distributions came from the same populations; there was no significant 2 difference with $X=0.38 ; p>.05(d f=1)$.

Question \#19--If a congregation does not favor a certain idea that is important to a minister, how should he react?

The results were significant at the 0.05 level with a chi square of 22.13 $(d f=1)$; the direction was as hypothesized (i.e., pastors were more Transformational than parishioners).

Question \#20--If a congregation favors a certain idea, but the minister does not favor it, how should he react?

Over fifty $(50 \%)$ percent of the responses to this question for both the pastors and the parishoners were coded neither Transformational or Transactional. Since responses were coded so overwhelmingly in the third category, "Other", the data in this question do not warrant statistical analysis.

BREADTH OF INVOLVEMENT was the concern of four questions:

Question \#10--In your experience, in what areas of church 1 ife does a congregation expect a minister to take leadership ( 1 ist)?

The results were not significant.

Question \#11--In your experience, in what areas of church life 
does a minister expect to take leadership (1ist)

The results were not significant.

Question \#15--What functions or activities mignt a minister delegate to lay people (1ist)?

The results were not significant.

Question \#16--What functions or activities might a minister reserve for himself (1ist)?

The results were significant at the 0.05 level with a chi square of $6.10(d f=1)$; the direction was as hypothesized (i.e., pastors were more Transformational than parishioners).

\section{Discussion}

The proposed difference between pastors and parishioners regarding Transformationa1/Transactional leadership was demonstrated in the responses to five of the fourteen open-ended questions, and, would have held in two other questions except for an oversight. On the coding manual one of the distinctions between Transformational and Transactional leadership was 1 isted as: "concerned beyond expressed needs (love, compassion, and concern for others)" as opposed to "addresses only expressed needs". This description is trying to summarize the notion that Transformational leaders put a nigher priority on people than on product, while Transactional leaders are interested in people only as they impact on product. I didn't realize that this distinction would present a problem until my co-coder asked how we were to differentiate between this concern beyond expressed needs and the concern that would be expected of church ministers; 
"After all", it was said, "Love your neighbor as yourself" and other statements are basic to what the church stands for"; see appendices 6 and 7. In retrospect, this concern should have been included originally. While a love factor might differentiate Transformational from Transactional leadership styles in general, it would not differentiate these leadership styles within the pastorate. If this one distinction on the coding manual had been modified, Questions 17 and 18 would have demonstrated a significant difference. As it was for statistical purposes the coding manual had to be followed as proposed; however, for discussion purposes the coders did note and record those responses coded as Transformational due to this one dimension alone.

\section{TRANSFORMATIONALITRANSACTIONAL QUESTIONS}

Three of these questions were significant; the significance was in the direction hypothesized (i.e., pastors were more Transformational than parishioners):

Question \#9--"A church must look to the future. How can a minister lead his church to the future (1 ist)"?-Question \#12--I think a minister should provide leadership in the following areas (list):--and

Question \#14--"If a minister is an effective leader, how would his church differ from other churches (1 ist)?"--

Regarding the concerns of these three questions, "the future", "providing leadership", and "being an effective leader", etc. parishioners tended to list measures related to a pastor's job description and to stress that a quality job would bring success, and, thus, they were often coded as Transactional. On the other hand, 
pastors' responses were coded significantly more as Transformational, because they tended to speak of planning for the future, being growth conscious, etc. Clearly, parishioners tend to look at church growth as tied to doing the same few things only better, while pastors see church growth resulting not only from doing a few things better, but resuiting from doing more things and from planning. In the Main study coding Manual the Transformational style is contrasted with the Transactional style: innovative versus satisfied, inquisitive versus waits for need to surface, takes initiative and encourages others to take initiative versus conforms and encourages others to conform, makes fundamental changes versus makes only minor changes, etc.

In the introduction, it was suggested that the tenure of pastors might be shortened by tensions arising from differing perspectives of leadership. The difference in perspective between pastors and parishioners found in the Transformational/Transactional leadership questions should be explored with this in mind. In this regard, I have heard Dr. Haddon Robinson, President of the Denver Seminary, speak on several occasions on church growth and change; his interest comes from desire to place pastors in churches where they will fit. He has stated that in his experience parishioners do not really want their churches to grow. If this is the case, parishioners might feel threatened by a Transformational leader but secure and happy with a Transactional leader. The literature suggests that Transformational leaders are as interested in maintaining an organization as Transactional leaders, and, therefore, take on new interests without ignoring the old interests. In this regard, like employers, pastors are in authority over parishioners, but like employees, they are dependent on others for 
a pay check; so to avoid the wrath of parishioners, pastors must take special pains not to ignore or appear to ignore the job description concerns. Parishioners can withdraw their support from their pastors or can make his ministry less of a joy and, thus, impact on the tenure of pastors.

Questions 7 and 8 mentioned above also looked at the basic distinctions of Transformational and Transactional leadership. For Question \#7 nineteen out of forty-four responses coded as transformational were done so because of the 'love' dimension. For Question \#8 ten out of fifty-five responses were likewise coded. I will return to this concern shortly.

\section{MODELING QUESTIONS}

While neither of the two modeling questions (17 and 18) was significant, it would be unwise to ignore them in a preliminary investigation like this one.

Question \#17--If a minister were to inspire someone to follow him, what would that minister be like or how would he behave (1ist)?--and

Question \#18--You may have heard the old adage "Some things are better caught than taught." What habits, convictions, traits, or the like would you expect a member to "catch" from a minister (1ist)?--

If the love dimension mentioned above had not been included, both questions would have been significant. In fact, of the 32 responses by parishioners in Question 17 coded as Transformational, 28 were done so 
only because of this love factor and of the 19 responses by congregants in Question 18 coded as Transformational, 18 were done so only because of this one factor Even though the questions did nut techniciliy demonstrate significance, there is reason to pursue "Modeling"! If we do set aside this love dimension, the resuits suggest that pastors do plan to serve as iransformational models, but congregants prefer them to be Transactional. The result might well be that the pastors' styie produces tense and resistant congregations, rather than eager followers. The Main study coding Manual demonstrates that Transformational leaders seek to gain eager followers by encouraging others to take initiative versus encouraging others to conform, by freeing people--the sky is the limit versus by restricting people-boundaries cherished, and by encouraging others to take leadership versus discouraging others from taking leadership. Parishioners might see many of the Transformational pastors' emphases and actions as window dressing, personal quirks, or irrelevant. For these and other reasons pastors need to be especially demonstrating (i.e.: modeling) a concern for the basics and for the ministries within the job description. A pastor models both when he presides over the liturgical meetings and when he attends to his broader leadership tasks. It would be interesting to measure whether pastors and parishioners prefer the first, which is largely performance and consistent with the conformity of Transactionalism or the second, which tends to allow for extemporaneous modeling and gives more opportunity for a Transformational leader to work.

Regarding the love factor, we can account for the many responses that relate to this one dimension as enumerated in the Bible (see 
Appendix 7), but how does one account for the difference in emphasis between the pastors and the parishioners? Along with the two questions on Modeling, this emphasis was also found in the parishioners' responses to Questions 7 and 8 , which were directed at the basic Transformational/Transactional distinction. It may be that parishioners and pastors see this dimension as equally important, but for different reasons; thus, the parishioner is saying, "If you will demonstrate (mode1) these in your own behavior, the church will grow (Questions 7 and 8) and I will personally follow you (Questions 17 and 18)", while the pastor is saying, "I exhibit certain things, not to promote growth or to inspire parishioners to follow me, but out of conviction." It may be that pastors do not realize how important this dimension is to the parishioners either to have the church run smoothly or to have the parishioners follow them. As pointed out elsewhere, the percentage of the parishioners' responses of this one dimension is great; however, the percentage of the pastors' responses is also surprisingly high. Since the literature on Transformational/Transactional leadership is largely based on business and political leaders, it would be interesting to check whether the importance of this dimension is Tikewise underestimated in those fields. Future study in church leadership might measure both the pastors' and the parishioners' interest in this 'love' concern in leadership and modeling issues.

\section{PERSEVERENCE QUESTIONS}

A significant difference in opinion between pastors and parishioners was demonstrated in the following question; the significance was in the direction hypothesized (i.e., pastors were more 
Transformational than parishioners).

--In your opinion, how many years should a minister plan to stay in any given church? years--

The pastors' responses to this question averaged 7.4 years, while the parishioners' responses averaged 14.6 years; this was a significant difference. Perhaps their hopes might be similar, but the pastors have a greater awareness of the reality that most pastors do not have long tenures. Perhaps pastors do not stay long, because they do not plan to stay long. Perhaps parishioners think ideally in the abstract, but fail to act out their ideals with real, flesh and blood, pastors. This two to one difference needs to be explored further. The literature suggests that pastors stay less than three years in any given church.

Question \#6--In your opinion, in what year of ministry in any given church does a minister reach his peak of effectiveness? _years--on the other hand, did not demonstrate a significant difference in opinion; the pastors' responses averaged 5.3 years, while the parishioners' responses averaged 5.65 years. The literature suggests that ministers reach their peak after the sixth year; therefore, either through an awareness of reality or through an awareness of the 1 iterature, both groups are on target in this case. If the responses to Question $\# 5$ and $\# 6$ are taken together, pastors allowed themselves 2.2 years of peak effectiveness before moving on, while parishioners allowed them nearly 7 years. A question arises as to why pastors would labor so long to reach the potential for effective ministry and then be satisfied with only 2.2 years of peak effectivenss before moving on. The answer may be that perseverence has its costs, as 
well as, its benefits. The larger question regarding perseverence also remains--why, given the responses to Questions 5 and 6 , do pastors stay in any given church such a short time?

Question \#19--"If a congregation does not favor a certain idea that is important to a minister how should he react?" was significant. While the Coding Manual stated that a Transformational leader is comfortable with pressure versus avoidng pressure situations in general, it specified that to be coded as Transformational an answer to this question had to indicate persevering, waiting, etc., whereas, to be coded Transactional an answer had to indicate giving up. The clear favorite response in the third category, "other", was praying; praying, and other religious jargon otherwise undescribed, might be related to persevering or to giving up. In future studies, if a similar open-ended questionnaire format is used, there must be an attempt to place responses with religious jargon within the Transformational/ Transactional framework, rather than always relegate them to the 'other' category. Many responses coded as 'Other' were well reasoned responses, although clearly not related to the two leadership styles. The significant difference suggests that pastors are more prepared for potential confrontation than the parishioners are. Further, it suggests that pastors see their job as sometimes encouraging the parishioners to go where they do not want to go, while the parishioners tend to feel that pastors should only go where the parishioners are comfortable going. These fit well into the basic Transformational/Transactional distinctions. Philosophically, if one thinks of tenure as related to persevering, then the significant result in Question 19 suggests that in dealing with a difference between a pastor and his parishioners in 
any given church one must know where the parties stand; i.e., are they expecting waiting or giving up? Pastors who persevere might be seen as dense (not fulty aware of the differences) or poor loosers (not willing to accept facts). Since pastors tend to stay only two or three years in a church, parishioners might see them as outsiders and might see themselves as owners and, thus, be further threatened. Parishioners might see their own interest as just, because they have long term stakes in their churches, while the pastors might appear to them as having only passing or professional interest. It would be interesting to measure whether pastors and parishioners see Question 19 (and its obverse pair, Question 20) through the eyes of an employee or an employer.

\section{BREADTH OF INVOLVEMENT QUESTIONS}

One question demonstrated significance in the hypothesized direction (i.e., pastors were more Transformational than parishioners): Question \#16--"What functions or activities might a minister reserve for himself (1ist)?--

The literature suggests that a leader must have broad interests and be involved beyond the job description, if he or she is to be a Transformational leader. The phenomenon of the written job description has only entered the church recently. older pastors do not think in terms of a formal job description; they do, however, have an idea of what their churches expect of them.

The significant difference suggests that pastors have this broad interest and involvement. It also suggests that the parishioners prefer 
to limit pastors to their job descriptions. This might be because the parishioners are less comfortable with change and/or they want the privilege of pacing the change and controling the direction of the changes. Somehow a pastor must be interested and involved broadly enough to encourage growth toward the future, while not triggering the insecurities of the congregants. What perception will the parishioners have when a pastor has broad interests or involvement in a church? He might be seen as not attending to his main duties as defined by his job description. If so, any problem in the church can easily be blamed on him. He might be seen as stepping on holy ground--the ground formerly controlled by one or more parishioners. People link their self-esteem to what they do and take loss or gain of control seriously. He might be seen as theoretical and not as practical. The standard within my denomination is for a minister to have four years of college and three years of graduate work; this makes him in most cases educated well beyond his congregation. It is important for a pastor to be perceived to be in touch with his congregation; a reputation for being an 'ivory tower' thinker wi11 hinder his ministry. He might be seen as liberai, which is a negative label in this denomination; liberalism has historically been associated with change. On the other hand, pastors may mistakenly take resistance to their broad based interest and involvement personal1y. A Transformational leader does perhaps run a greater risk of burning out. In a day when there are ever more job description demands on pastors, going beyond one's job description wil1 be done at a price. One price may be that he may not give due attention to the nuts and bolts ministries, because his attention is drawn to what he percieves as new and innovative ministries. 
What are some of the main contrasts in leadership comfort zones between pastors and parishioners? In terms of the basic Transformationa1/Transactional distinction--the parishioners want their leaders to stay close to the job description (written or understood); while pastors see the need of attending to the concerns of the job description, they also wanted to expend the job description and plan beyond the job description. In terms of modeling--pastors not only have the above conviction, they model their beliefs; parishioners, on the other hand, want their own convictions modeled by the pastor. In terms of perseverence--pastors are often willing to persever when there is disagreement with parishioners; parishioners want to see their own position adopted by the pastor. It has often been said, "What one man sees as perseverence, another man sees as stubbornness." In terms of Breadth of Involvement--parishioners find security in limiting a pastor to a job description; they limit change by pacing it and by controlling its direction. Pastors expressed interest in being invoived in many areas of church i ife.

\section{Limitations and Weaknesses}

The subject sampling was one of convenience. The pastors at best represented those who attended the specific denominational meeting. The parishioners at best represented those who attended their respective mid-week services in the four churches selected by the investigator. The investigator alone made the judgment that Modeling, Perseverence, and Breadth of Involvement are highlighted in the Pastoral Episties (see Appendix 1). On the other hand, the investigator has considerable background in making. such judgments and the original data, the Pastoral Epistles, are available for independent inspection. The investigator 
deeply regrets including the 'love dimension' in the coding manual. While this dimension might have utility in differentiating Transformational from Transactional perspectives in other settings, it is apparently out of place in this setting (see Appendix 7). During the coding process, the pastors' questionnaires were in one stack and the parishioners' questionnaires were in another. To avoid potential coder bias, questionnaires should have been randomly and blindly coded.

\section{Conclusion}

Not only does the basic concept of Transformational/Transactional church leadership warrant more study, but also the subconcepts of Modeling, Breadth of Involvement, and Persevering. Interesting questions need to be addressed. In response to Question \#5 regarding how long a pastor should stay in any given church parishioners' responses were twice that of pastors' responses; why is that? and why are both saying pastors should stay far longer than they actually do? How important is the 'love' dimension to church leadership? and why do the parishioners seem to consider it so important as compared to the pastors? Is this 'love' dimension underestimated in leadership studies outside of the church? These questions and others lead us closer to answering the question of whether tension caused by this Transformationa1/Transactional church leadership bifurcation impacts on the duration of pastorates. It is hoped that the more general theory of Transformational/Transactional leadership is furthered by this study, which operationalizes and extends this leadership perspective into a religious setting.

Research will benefit from the sampling of responses from pastors and parishioners in this study; in terms of methodology, future studies 
may be made more practical (both in terms of the time it takes subjects to fill out questionnaires and the time it takes to extract the data from the questionnaire) by utilizing a Likert-type scale rather than the open-ended question format. Three basic assumptions of this research are that there is a difference between pastors and parishioners along Transformational/Transactional lines, that this difference leads to friction between congregants and pastors, and that this friction causes pastors to have brief tenures. This study has demonstrated the validity of the first assumption; the second and third assumptions may be addressed. Now that this theory has entered the religious setting, comparative studies may prove beneficial. This was a study of Conservative Baptist pastors and parishioners in New England. Future studies could go beyond New England and beyond Conservative Baptists. A study comparing Protestants with Roman Catholics and/or Jews might be profitable. 
Appendix 1--Summary of Verse by Verse Analysis of the Pastoral Episties

In an attempt to discover the leadership concerns of the Pastoral Epistles I registered summary statements under the headings of Position/Title, Qualifications, and commands regarding Personal Relationships, Meeting Needs, Modeling, Things To Be Avoided, The Teaching/Preaching Duty, other Duties, and Persevering; the "Other Duties" category demonstrated that a Breadth of Involvement was expected. Below are summaries of the commands found that relate to the three specific transformational concepts dealt with in this study. growth).

Book, Chapter, Verse Modeling other Duties

Persevering

I Iimothy 1

3

Command

Stay

18

Fight...fight

19

Holding on

I Iimothy 2

I Iimothy 3

Take care

13

Serve

\section{I imothy 4}

7 Train yourself

Command

12 Set an example in speech, life, love, faith, purity

Devote

Don't let

Don't neglect 


$$
\text { Appendix 1--Summary... (cont.) }
$$

Book, Chapter, Verse

Modeling

Other Duties

I Timothy 4 (cont.)

15 Progress

16 Watch 1 ife, doctrine

I Iimothy 5

17

22

I Iimothy 6

11 Pursue righteousness, godliness, faith, love, endurance, gentieness

Direct affairs of church Preach
Persevering

Be diligent

Give wholly

Persevere

Keep pure

Endurance

Fight

Take hold

17

Command

18

Command

20

Entrust to your care

Guard

II I imothy 2

6

8

II Iimothy 2

1

2 Entrust

3

7 Reflect
Fan into flame

Don't Be ashamed Join

Keep

Guard

Be strong

Endure 


$$
\text { Appendix 1--Summary... (cont.) }
$$

Book, Chapter, Verse Mode Iing

II Iimothy 2 (cont.)

8 Remember

14

Keep Reminding

Warn

15 Present

22 Pursue righteousness,

faith, love, peace

Pursue... (also here)

\section{I imothy 3}

1 Mark this

14

Continue

II Timothy 4

2

5

\section{Titus 1}

5

7

9

11

13

Titus 2

6

7 Set Example
Preach, Be Prepared, Correct, Rebuke, Encourage

Do Work of An Evange list Discharge All Duties

Keep Head Endure Hardship

Great Patience
Straighten Out

Appoint

Entrusted With God's Work

Encourage

Refute

Silence

Rebuke

Encourage 
Appendix 1--Summary... (cont.)

Book, Chapter, Verse

Modeling

Other Duties

Persevering

Titus 3

1

Remind

8

Stress

9

Warn 
Appendix 2--Questionnaire

\section{Questionnaire page 1}

(When asked to 'list', please make your list as specific as possible)

1. Age:

2. Sex (check one): _male _ female

3. Check one:

- church member

How many years have you been an active member (circle one)?

$\begin{array}{lllllllllllll}0 & 1 & 2 & 3 & 4 & 5 & 6 & 7 & 8 & 9 & 10 & \text { or more (years) }\end{array}$

- church minister

How many years have you served in each ministry?

$$
\begin{aligned}
& \text { present church }- \text { years } \\
& \text { next previous } \quad \text { years } \\
& \text { next previous } \quad \text {-years } \\
& \text { next previous - years }
\end{aligned}
$$

4. How many years have you been a Christian (circle one)?

$$
\begin{array}{lllllllllllll}
0 & 1 & 2 & 3 & 4 & 5 & 6 & 7 & 8 & 9 & 10 & \text { or more (years) }
\end{array}
$$

5. In your opinion, how many years should a minister plan to stay in any given church? - years

6. In your opinion, in what year of ministry in any given church does a minister reach his peak of effectiveness? _ year

7. How does a minister keep a church running smoothly (1 ist)?

8. How does a minister help a church reach its potential (1ist)? 
9. A church must look to the future. How can a minister lead his church to the future?

10. In your experience, in what areas of church life does a congregation expect a minister to take leadership (1ist)?

11. In your experience, in what areas of church life does a minister expect to take leadership ( 1 ist)?

12. I think a minister should provide leadership in the following areas (1 ist):

13. I think a minister should not provide leadership in the following areas (1ist): 
14. If a minister is an effective leader, how would his church differ from other churches (1ist)?

15. In what functions or activities of the church should a minister be involved ( 1 ist)?

16. In what functions of activities of the church should a minister not be involved (1ist)?

17. If a minister were to inspire someone to follow him, what would that minister be like or how would he behave (list)?

18. You may have heard the old adage "Some things are better caught than taught." What habits, convictions, traits, or the like would you expect a member to "catch" from a minister (1ist)? 


\section{Questionnaire page 4}

19. If a congregation does not favor a certain idea that is important to a minister, how should he react?

20. If a congregation favors a certain idea, but the minister does not favor it, how should he react?

21. Suppose a minister wants a church to adopt some change. Should he seek that change through his pulpit ministry, church boards, personal relationships, business meetings, or some other means? Please explain your answer. 
Appendix 3--Verification of Question Grouping

Below is the letter used to recruit and introduce students for the process of verification of the question grouping:

Dear Fellow graduate students:

I am utifizing an open-ended questionnaire as part of my Master's thesis research. I need to verify that the questions get at the issues I intend.

The basic concern of the questionnaire is church leadership. The specific theory is concerned with 'transactional' leadership (interested in maintaining the status quo) and 'transformational' leadership (interested in reaching beyond status quo in order to achieve potential). Three specific areas where a distinction between transactional and transformational leadership might be seen are in modeling, in persevering, and in breadth of involvement. Modeling has to do with the leader providing an example for followers. Perseverence has to do with the leader staying with an idea or a church despite negative responses. Breadth of involvement has to do with whether the leader is only interested in being involved in a few areas or in many areas.

I am asking you to sort twenty-one (21) cards, each with a question on it. I would like you to place each card into one of five groups:

Those questions which get at the general issues (basic distinctions as opposed to specific aspects) of transformational and transactional Teadership.

Those questions which get at (most specifically) the modeling 
aspect of transformational and transactional leadership.

Those questions which get at (most specifically) the persevering aspect of transformational and transactional leadership.

Those questions which get at (most specifical?y) the preadth of involvement aspect of transformational and transactional leadership.

Those questions which may be useful in a follow up study or which do not get at the general or specific issues of transformational and transactional leadership.

Thank you for your assistance.

Sincerely,

Jim Bray 
Dear Volunteer,

Thank you for agreeing to assist me by scoring questionnaires.

You wi11 need to understand the distinction between transformational and transactional perspectives in order to categorize and label responses. In general a transformational response would be positively disposed to change toward reaching potential, while a transactional response would consider maintaining the status quo as very important. You will be labeling responses as 'transformatonal, 'trarisactiona ${ }^{\prime}$, or 'other'. More specific distinctions are drawn below.

TRANSFORMATIONAL

future oriented

willing to take risks

interested in improving

innovative

inquisitive

forcefully acts

long-term oriented

on the cutting edge

intitiative

conceptual

concerned with high standards

comfortable with change

willing to make waves

broad interests

willing to invest

growth conscious

willing to take a stand

transforming

comfortable with shifts in power

visionary

ahead of the pack

freeing--the sky is the limit comfortable even without limits interested in moral implications asking: what if?

concerned beyond expressed needs comfortable with pressure

comfortable with shifts in

$$
\text { expectations }
$$

makes fundamental changes

\section{TRANSACTIONAL}

past oriented

avoiding risks

interested in maintaining

satisfied

waits for need to surface

slow to act

short-term oriented

plays it safe

conformity

pragmatic

concerned with average performance uncomfortable with change

unwilling to make waves

narrow interrests

avoiding investing

stability conscious

preferring to let another try

first

conforming

uncomfortable with shifts in power reactionary

with the pack

restricting--boundaries cherished comfortable only with limits

interested mostly in bottom ine

saying: if it ain't broke, don't

fix it!

addresses on $7 y$ expressed reeds

avoiding pressure situations

uncomfortable with shifts in

expectations

makes only minor changes 
Appendix 5--Informed Consent Form

Dear Prospective Participant:

I am a graduate student in Psychology at the University of Rhode Island, as well as, a Baptist minister. I would like to enlist your cooperation in a research project about church relationships. I am asking that you fill out the attached questionnaire; this will take approximately 30 minutes of your time; there is no risk to you. I think you will find it interesting.

Your name will not be connected in any way with your responses to the questions asked. Your answers are completely ANONYMOUS and confidential and are being solicited only for the purposes of this research project. If you decide after you have begun to participate that you would not like to continue, you may stop at any time.

If you agree to take part in this research please sign the INFORMED CONSENT FORM at the bottom of this page. This form will go directly into a separate file and will never be associated with your answers. There is a place on the form below where you may indicate if you would like a summary of my findings.

\section{Sincerely,}

Rev. James L. Bray

\section{INFORMED CONSENT FORM}

I have read the above and agree to participate in the research described.

$$
\text { (name) }
$$

(date)

please send me a summary report there is no need to send me a summary report 
Appendix 5--Main Study Coding Manual

Thank you for agreeing to assist me by scoring questionnaires.

You wi11 need to understand the distinction between transformational and transactional perspectives in order to categorize and label responses. In general a transformational response would be positively disposed to change toward reaching potential or moving expectations, while a transactional response would consider maintaining the status quo or maintaining expectations as very important. You will be labeling responses as 'transformational', 'transactional', or 'other'. More specific distinctions are drawn below.

TRANSFORMATIONAL

future oriented

willing to take risks

interested in improving

innovative

inquisitive

forcefully acts

long-term oriented

on the cutting edge

takes intitiative and encourages others to take initiative

conceptua 1

concerned with high standards comfortable with change

willing to make waves

broad interests

willing to invest

growth conscious

willing to take a stand

transforming

comfortable with shifts in power visionary

ahead of the pack

freeing people--the sky is the limit
TRANSACT IONAL

past oriented

avoiding risks

interested in maintaining

satisfied

waits for need to surface

slow to act

short-term oriented

plays it safe

conforms and encourages others to conform

pragmatic

concerned with average performance uncomfortable with change

unwilling to make waves

narrow interrests

avoiding investing

stability conscious

preferring to let another try first

conforming

uncomfortable with shifts in power reactionary

with the pack

restricting people--boundaries cherished 
comfortable even without iimits interested in mora? implications asking: what if?

concerned beyond expressed needs

(love, compassion, and concern for others)

comfortable with pressure comfortable with shifts in expectations

makes fundamental changes

encourages others to take take Teadership

involved beyond job description duties comfortable only with limits

interested mostiy in bottom line saying: if it ain't broke, don't fix it!

addresses on $1 y$ expressed needs

avoiding pressure situations uncomfortable with shifts in expectations

makes on $7 y$ minor changes

discourages others from taking leadership

involved only in job description duties

TYPICAL JOB DESCRIPTION DUTIES:

preach and teach, disciple, counsel, assist boards and committees, observe ordinances, evangelize, teach in sunday School, officiate at public gatherings, visit, perform weddings and funerals, some but limited community involvement, correspondence, etc.

Questions that look at the basic transformational/transactional distinction are: $7,8,9,12,13$, and 14 .

Questions that look at modeling are: 17 and 18 .

Questions that $100 \mathrm{k}$ at perseverence are: 5, 6,19 , and 20.

Questions that look at breadth of involvement are $10,11,15$, and 16 . Coding specific questions:

10, 11, 15, and 16-- "A" for job description items, " 0 " for other or mundane items, " $F$ " for beyond job description items. (After subtracting A's and O's, compare the number of F's.)

12 and 13--"A" for 1 imited to job description items, "O" for other or for freeing from mundane items, " $F "$ for allowing freedom beyond job description items. 
19 and 20-- $A$ " for giving up, " 0 " for question or other, "F" for persevering.

In the pilot study coders found questions 15 and 16 difficult. One concern was whether ministers were being restricted from or being freed from items that might be mundane. I am suggesting that Questions 15 and 16 be reworded. Along with Questions 10 and 11, they are attempts to understand the Breadth of Involvement. We might compare total responses of ministers and congregants we might compare total " $A$ " and " $F$ " responses or compare " $F$ " responses; we might compare the responses of 10 to those of 11 and the responses of 15 to those of 16 . If ministers are more transformationally oriented than congregants, then they should assume that the ministers will be interested and involved more broadly than congregants desire or anticipate.

0ld question 15--What functions or activities might a minister delegate to lay people (1 ist)?

New question 15--In what functions or activities of the church should a minister be involved (1ist)?

01d question 16--What functions or activities might a minister reserve for himself (1ist)?

New question 16--In what functions or activities of the church should a minister not be involved (1ist)? 
Appendix 7--Love's centrality

In the Main Study Coding Manual one distinction between the two leadership perspectives was "concerned beyond expressed needs (love, compassion, and concern for others)"--Transformational--and "addresses only expressed needs"--Transactional. As noted earlier, a number of responses were coded as Transformational due to this distinction. The coders noted that these responses were so coded because the responses included the word love or loving.

As a christian and as a minister I can attest that love has long been considered central to church 1 ife. In Matthew 22 when Jesus was asked which was the greatest commandment in the Law, He replied, "Love the Lord your God with all your heart and with al1 your soul and with a11 your mind'. This is the first and greatest commandment. And the second is like it: 'Love your neighbor as yourself.' All the Law and the Prophets hang on these two commandments." In John 13 Jesus prepared His disciples for His death by saying: "A new command I give you: Love one another. As I have loved you, so you must love one another. A11 men will know that you are my disciples if you love one another." Perhaps the best loved chapter of the Bible is Paul's description of love's greatness in First corinthians:

"If I speak in the tongues'of men and of angeis, but have not love, I am only a resounding gong or a clanging cymbal. If I have the gift of prophecy and and can fathom al1 mysteries and ali knowledge, and if I have a faith that can move mountains, but have not love, I am nothing. If I give a11 I possess to the poor and surrender my body to the flames, but have not love, I gain nothing.

"Love is patient, love is kind. It does not envy, it does not boast, it is not proud. It is not rude, it is not self-seeking, it is not easily angered, it keeps no record of wrongs. Love does not delight in evil but rejoices with the truth. It always protects, always trusts, always hopes, 
always perseveres.

"Love never fails...

"And now these three remain: faith, hope, and love. But the greatest of these is love."

James, the brother of Jesus, wrote that the 'Royal Law' is "Love your neighbor as yourself." In Peter's First Epistle he said that those Christians he was writing to were to "love one another deeply, from the heart." Finally, John's First Epistle says: "This is the message you heard from the beginning: We should love one another."

Because love is so central to church life, the dimension that included it should not have been used to distinquish Transformational leadership from Transactional leadership in this study; this was a major oversight. On the other hand, perhaps its greater importance to parishioners than to pastors might have been overlooked otherwise. 
Andriessen, Erik J. H. and Drenth, Pieter, J. D. (1984). Leadership: theories and models. In P. J. Drenth, H. Theirry, P. J. Nillems and D. J. de Wolff (Eds.), Handbook of work and organizational psycholgy. (pp. 481-520). New York: John Wi ley and Sons.

Bandura, Albert (1986). Social foundations of thought and action: A social cognitive theory. Englewood Cliffs, NJ: Prentice-Hall.

Bass, Bernard M. (1985). Leadership and performance beyond expectation. New York: The Free Press.

Bible--New international version. (1983). Grand Rapids, Michigan: Zondervan.

Burns, James MacGregor. (1978). Leadership. New York: Harper and Row. Cohen, J. A. (1960). A coefficient of agreement for nominal scales. Educational and Psychological measurement, 20, 37-46.

Dea1, Terrence E. and Kennedy, Allan A. (1982). Corporate cultures: the rites and rituals of corporate life. Reading, Mass: AddisonWesley Pub. Co.

George, Carl F. (1987). The berry bucket balance. Leadership, VIII, $4,52-57$.

Gordon, Judith R. (1987). A diagnostic approach to organizational behavior. (Second Edition). Boston: Allyn and Bacon Harris, Philip R. (1985). Management in transition. San Francisco: Jossey-Bass. 
Hersey, Paul and Blanchard, Kenneth H. (1972). Management of prganizational behavior. (Second Edition). Englewood Cliffs, N.J.:

Prentice-Hall.

Hollander, Edwin P. (1985). Leadership and power. In The handbook of social psychology. (Third Edition; Vol. 2). New York: Random House. $485-537$.

Levy, Amir and Merry, Uri. (1986), Organizational transformation: approaches, strategies, theories. New York: Praeger.

Tichy, N. M. and Ulrich, D. O. (1984). A call for the transforma-

tional leader. Sloan Management Review, 26, 59-68. 